\title{
Acteoside, a Component of Stachys Sieboldii MIQ, May Be a Promising Antinephritic Agent (3): Effect of Acteoside on Expression of Intercellular Adhesion Molecule-1 in Experimental Nephritic Glomeruli in Rats and Cultured Endothelial Cells
}

\author{
Kazumi Hayashi ${ }^{1}$, Tadashi Nagamatsu ${ }^{1}$, Mikio Ito $^{1}$, Hideo Yagita ${ }^{2}$ and Yoshio Suzuki ${ }^{1, *}$ \\ ${ }^{1}$ Department of Pharmacology, Faculty of Pharmacy, Meijo University, 150 Yagotoyama, Tenpaku-ku, Nagoya 468, Japan \\ ${ }^{2}$ Department of Immunology, Juntendo University School of Medicine, Hongo 2-1-1, Bunkyo-ku, Tokyo 113, Japan
}

Received August 28, 1995 Accepted November 13, 1995

\begin{abstract}
It is known that adhesion molecules play a crucial role in the development of glomerulonephritis. Therefore, we investigated the effects of acteoside on the expression of intercellular adhesion molecule-1 (ICAM-1) in nephritic glomeruli, in vivo, and human umbilical vein endothelial cells (HUVECs) and rat mesangial cells, in vitro. Acteoside treatment significantly decreased the up-regulation of ICAM-1 expression in nephritic glomeruli. Acteoside prevented the up-regulation of ICAM-1 expression mediated by inflammatory cytokines or phorbol 12-myristate 13-acetate on HUVECs and rat mesangial cells. Adhesion of neutrophils and macrophages to acteoside-treated HUVECs was suppressed to one half of that in untreated HUVECs. These data support the finding that acteoside inhibits the up-regulation of ICAM-1 in the nephritic glomeruli. Additionally, it is suggested that the antinephritic action of acteoside is due to the inhibition of intraglomerular accumulation of leukocytes through the prevention of the upregulation of ICAM-1. This is the first paper demonstrating that the up-regulation of ICAM-1 in nephritic glomeruli is inhibited by a natural product, acteoside.
\end{abstract}

Keywords: Acteoside, Anti-GBM nephritis, Adhesion molecule, Neutrophil, Endothelial cell

Adhesion-promoting molecules appear to play an important role in development of the inflammatory response and the recruitment of leukocytes into tissues $(1-4)$. Requirements for adhesion-promoting molecules have been determined in nephritis. Recent studies have demonstrated the importance of various adhesion-promoting molecules in the leukocytic accumulation in nephritic glomeruli and glomerular damage in human and experimental nephritis $(2,5-8)$. These studies have shown that intercellular adhesion molecule-1 (ICAM-1), which is expressed on many cell types including endothelium and has as its ligands members of the $\beta_{2}$-integrin family, leukocyte function-associated antigen-1 (CD11a/CD18, LFA-1) and macrophage activation complex-1 (CD11b/CD18, Mac-1), appears to be functionally the most important adhesion molecule in directing glomerular leukocytic infiltration. It was reported that monoclonal antibodies against ICAM-1, LFA-1, Mac-1 and very late activating

* To whom correspondence should be addressed. antigen-4 (CD49d/CD29, VLA-4) decreased urinary protein excretion and the accumulation of leukocytes in glomeruli in experimental anti-glomerular basement membrane (GBM) nephritis $(5,6)$.

Our previous study (9) demonstrated that acteoside, a component of Stachys sieboldii MIQ, was effective against crescentic-type anti-GBM antibody-induced nephritis in rats. Furthermore, it has been suggested that the antinephritic effect of acteoside is mediated by inhibition of the cell-mediated immune response (10). However, acteoside did not suppress interleukin (IL)-2 production by isolated mouse spleen cells when they were stimulated by concanavalin A (ConA) and leukotriene (LT) $B_{4}$ production by isolated glomeruli in nephritic rats (K. Hayashi et al., unpublished data). The aim of this study is clarify the mechanism through which acteoside inhibits leukocyte migration into nephritic glomeruli.

The majority of in vitro studies describing leukocyte endothelial interactions was performed with cultured human umbilical vein endothelial cells (HUVECs). 
Because renal endothelium, and particularly glomerular endothelium, from rats has been difficult to culture, few studies have evaluated the response of rat glomerular endothelial cells to cytokines. Briscoe and Cotran (11) reported that human glomeruli as well as HUVECs responded to inflammatory cytokines to express ICAM-1, vascular cell adhesion molecule-1 (VCAM-1) and endothelial leukocyte adhesion molecule-1 (ELAM-1). It has been reported that in an in vitro cultured kidney organ model, ICAM-1 is weakly expressed on human glomerular endothelial cells, but ELAM-1 and VCAM-1 are not expressed on the cell, and the expression of these adhesion molecules dramatically increase in response to inflammatory cytokines (11). Nikolic-Paterson et al. (12) reported that while isolated rat glomeruli do not normally express E-selectin and only weakly express VCAM-1, an increase in E-selectin and VCAM-1 gene expression occur in response to IL-1 and LPS. These reports suggest that the up-regulation of adhesion molecules on activated HUVECs reflect the up-regulation of adhesion molecules on glomerular endothelial cells stimulated by inflammatory cytokines. Therefore, we used HUVECs to study the effect of acteoside on adhesion molecule expression and leukocyte adhesion to endothelial cells in this experiment. Furthermore, we investigated the effect of acteoside on ICAM-1 expression in cultured rat mesangial cells to confirm whether acteoside was able to inhibit the ICAM1 expression in intrinsic glomerular cells.

\section{MATERIALS AND METHODS}

\section{Animals}

Male Sprague-Dawley strain rats, weighing approximetly $160 \mathrm{~g}$ (Nihon SLC, Hamamatsu), were used in all experiments. These animals were housed in an air-conditioned room at $23 \pm 1{ }^{\circ} \mathrm{C}$ during the experimental period.

\section{Drugs}

Acteoside (Tsumura Co., Ltd., Tokyo) was extracted from the aerial part of chorogi (Stachys sieboldi MIQ). For the in vivo experiment, acteoside was dissolved in distilled water, and cyclosporin A (Sandoz Co., Ltd., Tokyo) was dissolved in 5\% ethanol in olive oil. For the in vitro experiments, acteoside was dissolved in RPMI 1640 (Nissui Pharmaceutical Co., Ltd., Tokyo), and cyclosporin A was dissolved in ethanol with $20 \%$ Tween 80 at $1 \times 10^{-2} \mathrm{M}$ and was then diluted in RPMI 1640 to the desired concentration. FK506 (Fujisawa Co., Ltd., Osaka) was dissolved in ethanol at $1 \times 10^{-2} \mathrm{M}, \mathrm{H}-7$ (Seikagaku Co., Ltd., Tokyo) and genistein (Wako Pure Chemical Industries Co., Ltd., Osaka) were dissolved in RPMI 1640 at $1 \times 10^{-1} \mathrm{M}$. Staurosporin (Kyowa Medex Co., Ltd., Tokyo) was dissolved in dimethyl sulfoxide at
$1 \times 10^{3} \mathrm{M}$. Recombinant human tumor necrosis factor (TNF)- $\alpha$, recombinant human IL-1 $\beta$ and anti-cytokine neutralizing antibodies (rabbit anti-human TNF- $\alpha$ polyclonal antibody and rabbit anti-human IL-1 $\beta$ polyclonal antibody) were purchased from Genzyme (Cambridge, MA, USA). Recombinant rat TNF- $\alpha$ was purchased from Biosource International (Camarillo, CA, USA). PMA was purchased from Sigma (St. Louis, MO, USA). Monoclonal antibodies to ICAM-1 (CD54), LFA-1 (CD11a), Mac-1 (CD11b) and VLA-4 (CD49d) were purchased from Seikagaku Co., Ltd.

\section{Induction of crescentic-type anti-GBM nephritis}

Crescentic-type anti-GBM nephritis was induced by immunizing the rats that had received a nephritogenic dose $(0.6 \mathrm{ml} /$ animal, i.v.) of rabbit anti-rat GBM serum with rabbit $\gamma$-globulin according to the previously reported method (9).

\section{Administration of test drugs}

Twenty-four hour urine samples were collected immediately after the anti-GBM serum injection into rats. These rats were then divided into 3 groups $(n=5)$, so that the average protein content in the 24-hr urine in each group was at the similar level. Rats in two groups were orally given, once daily, acteoside at $30 \mathrm{mg} / \mathrm{kg}$ and cyclosporin A at $20 \mathrm{mg} / \mathrm{kg}$, respectively, in a volume of $1 \mathrm{ml}$ per $100 \mathrm{~g}$ of body weight, from the day (1 day) after the anti-GBM serum injection to either 5 or 15 days after. The remaining one group was orally given the vehicle (distilled water) instead of test drugs and served as the control. In addition, a normal group $(n=5)$ was used in the experiment for comparison with the nephritic groups.

\section{Determinations of urinary protein}

Twenty-four hour urine samples after the administration of test drugs for 15 days were collected for the determination of urinary protein as previously reported (9). The urinary protein content was determined by the method of Kingsbury et al. (13) and the results are expressed as $\mathrm{mg} / 24 \mathrm{hr}$ urine.

\section{Immunohistochemical studies}

At the time of killing, renal tissue samples were fixed in $10 \%$ formalin buffer for immunoenzymatic staining. Immunocytochemical studies were performed on paraffin sections $(2-3-\mu \mathrm{m}$-thick). Nonspecific binding was blocked by treating the sections with normal rabbit serum for $30 \mathrm{~min}$. The sections were then sequentially incubated with an monoclonal antibody (mAb) to ICAM-1 or LFA1, rabbit anti-mouse immunoglobulin $\mathrm{G}$, and horseradish peroxidase-avidin biotin complex. The sections were developed with $3,3^{\prime}$-diaminobenzidine-tetrahydrochlo- 
ride. Each stained tissue section was analyzed with an image analyzer (Toyobo Image analyzer V1; Toyobo Co., Ltd., Tokyo) to determine the total area of ICAM-1 and the number of LFA-1-positive cells in the glomeruli, and results are expressed as $\mathrm{mm}^{2}$ per glomerular cross section (G.C.S.) or the number of cells per G.C.S. (10).

\section{Cell culture}

HUVECs: HUVECs were obtained from Curabou (Neyagawa). The cells were suspended in culture medium (MCDB131 with 2\% fetal bovine serum (FBS), $10 \mu \mathrm{g}$ heparin $/ \mathrm{ml}, 10 \mu \mathrm{g}$ endothelial cell growth supplement $/ \mathrm{ml}, 10 \mu \mathrm{g}$ epidermal growth factor $/ \mathrm{ml}, 1 \mu \mathrm{g}$ hydrocortisone $/ \mathrm{ml}, 50 \mu \mathrm{g}$ gentamicin $/ \mathrm{ml}, 0.25 \mu \mathrm{g}$ amphotericin $\mathrm{B} / \mathrm{ml}$ ) (Curabou) and grown in $75-\mathrm{cm}^{2}$ tissue culture flasks (Becton Dickinson, Franklin Lakes, NJ, USA). The culture medium was changed twice weekly. HUVECs were trypsinized when they were subconfluent, resuspended in culture medium, and either seeded into new culture flasks or collagen-coated plates (24- or 96well). HUVECs were used from the 3 rd to 6 th passage.

Mesangial cells: Kidneys were harvested from pentobarbital-anesthetized $150-200 \mathrm{~g}$ Sprague-Dawley rats after in situ perfusion with cold phosphate-buffered saline (PBS). Isolation of glomeruli was performed under sterile conditions. Kidneys were decapsulated and the cortex separated from the underlying medulla. Cortical fragments were ground to a pulp and pressed through a 250 $\mu \mathrm{m}$ brass sieve. Material collected from the underside was washed successively through $150-\mu \mathrm{m}$ and $75-\mu \mathrm{m}$ sieves to retain the tubular fragments and the glomeruli, respectively. The glomeruli were resuspended and washed three times in PBS. The resulting glomerular cores (at least 90\% pure when assessed by light-microscopy) were resuspended in medium, plated in $25-\mathrm{cm}^{2}$ tissue culture flasks (Becton Dickinson) and maintained in RPMI 1640 supplemented with 20\% heat-inactivated FBS (Gibco, Grand Island, NY, USA), insulin $(5 \mu \mathrm{g} / \mathrm{ml})$ (Sigma), transferrin $(5 \mu \mathrm{g} / \mathrm{ml})$ (Biomedical Technologies, Inc., Stoughton, MA, USA), penicillin $(100 \mu \mathrm{g} / \mathrm{ml})$ (Sigma), streptomycin $(100 \mu \mathrm{g} / \mathrm{ml})$ (Sigma) and glutamine $(300$ $\mu \mathrm{g} / \mathrm{ml})(\mathrm{Gibco})$. Cultures were maintained in a humidified incubator at $37^{\circ} \mathrm{C}$ in $5 \% \mathrm{CO}_{2}$. The medium was changed every 4 days, and the cells were subcultured with trypsin (0.05\%) (ICN Biomedicals, Inc., Costa Mesa, CA, USA) - ethylenediamine tetraacetic acid (EDTA) $(0.02 \%)$ (Cosmo Bio Co., Ltd., Tokyo) when they had become confluent ( $7-10$ days).

\section{Cell ELISA}

HUVECs $\left(1 \times 10^{4}\right.$ cells/well) were seeded into 96-well, flat-bottomed human-type-I collagen coated plates (Sumitomo Bakelite Co., Ltd., Tokyo) in $100 \mu$ of M199
(Nissui Pharmaceutical Co., Ltd.) and allowed to reach subconfluency (approximately $10^{5} \mathrm{cell} /$ well). Rat-mesangial cells $\left(1 \times 10^{4}\right.$ cells/well) were seeded into 96-well, flat-bottomed rat-type-I collagen-coated plates (Becton Dickinson) in $100 \mu \mathrm{l}$ of RPMI 1640 and allowed to reach subconfluency. When HUVECs or rat mesangial cells were subconfluent, $100 \mu \mathrm{l}$ of the medium from each well was removed, and then $50 \mu \mathrm{l}$ of the RPMI 1640, various agents or anti-cytokine neutralizing antibodies were added to the appropriate wells. Immediately or $2 \mathrm{hr}$ after addition of various drugs (acteoside, FK506, cyclosporin A, H-7, staurosporin, genistein), $50 \mu \mathrm{l}$ of cytokines (final concentration: recombinant human TNF- $\alpha$ at $100 \mathrm{U} / \mathrm{ml}$, recombinant human $\mathrm{IL}-1 \beta$ at $125 \mathrm{U} / \mathrm{ml}$, recombinant rat TNF- $\alpha$ at $100 \mathrm{U} / \mathrm{ml}$ ), PMA (final concentration: 100 $\mathrm{ng} / \mathrm{ml}$ ) or medium was added to each appropriate well to yield a final volume of $100 \mu \mathrm{l} /$ well. The cultures were incubated for 4,12 or $20 \mathrm{hr}$ at $37^{\circ} \mathrm{C}$ in $5 \% \mathrm{CO}_{2}$. The cell monolayer was washed twice with Hank's balanced salt solution (HBSS; Sanko Junyaku Co., Ltd., Tokyo) and then fixed with $1 \%$ paraformaldehyde for $15 \mathrm{~min}$ at room temperature. After washing the fixed HUVEC three times with HBSS, the unbound sites were blocked by casein (Block A ${ }^{(\mathbb{B}}$; Yukizirushi Co., Ltd., Sapporo) diluted in HBSS and incubated at $37^{\circ} \mathrm{C}$ for $1 \mathrm{hr}$ in $5 \% \mathrm{CO}_{2}$. The blocking solution was removed by aspiration from the plate. A total of $100 \mu \mathrm{l}$ of mAb (anti-ICAM-1, VCAM-1 (Genzyme Co., Ltd.) or ELAM-1 (Seikagaku Co., Ltd.)) was added to each well and the plates were incubated at $37^{\circ} \mathrm{C}$ for $1 \mathrm{hr}$. The plates were removed and the culture wells were washed three times with HBSS. After the last wash, $100 \mu 1$ of a $1 / 2000$ dilution of the secondary antibody (goat anti-mouse IgG $(\mathrm{H}+\mathrm{L})$ horseradish peroxidase conjugate; Bio-Rad Lab. Co., Ltd., Richmond, CA, USA) in RPMI 1640 was added. The plates were then incubated for $1 \mathrm{hr}$ at $37^{\circ} \mathrm{C}$ in $5 \% \mathrm{CO}_{2}$. After washing with PBS, o-phenylenediamine (Sigma) development was determined by measuring the optical density at $490 \mathrm{~nm}$ with a microplate reader (model 3550 Microplate reader; BioRad Lab. Co., Ltd.).

\section{Neutrophil (PMN) and macrophage preparation and ${ }^{5 I} \mathrm{Cr}$ labeling}

PMNs or macrophages were collected from rats that were peritoneally injected with $1 \%(\mathrm{w} / \mathrm{v})$ casein (Wako Pure Chemical Industries Co., Ltd.) 4 or $15 \mathrm{hr}$ before the collection. The final pellet was suspended in M199 and contained about $95 \%$ PMNs or macrophages, as determined by light microscopy. For studies of adhesion, PMNs and macrophages were radiolabeled with sodium chromate $\left({ }^{51} \mathrm{Cr}\right)\left(3.7 \mathrm{MBq} / 10^{8}\right.$ cells; Daiichi Pure Chemicals, Chiba) for $60 \mathrm{~min}$ at $37^{\circ} \mathrm{C}$, and then they were washed three times in M199 to remove extracellular ${ }^{51} \mathrm{Cr}$ and 
resuspended in M199 containing 10\% bovine serum albumin (Sigma).

PMNs or macrophage adhesion to HUVEC monolayers

For studies of adhesion, HUVECs were grown to subconfluence in HUVEC medium on type I collagen coated 24-well tissue culture plates (Sumitomo Bakelite Co., Ltd.). HUVECs were treated with various concentrations of acteoside, $\mathrm{H}-7$ or cyclosporin A, and TNF- $\alpha$ (final 100 $\mathrm{U} / \mathrm{ml}$ ) or medium were added simultaneously to each well. The plate was incubated for $4 \mathrm{hr}$ at $37^{\circ} \mathrm{C}$ in $5 \%$ $\mathrm{CO}_{2}$. The HUVECs were subsequently washed. PMNs $\left(0.4 \mathrm{ml}\right.$ with approximately $\left.1 \times 10^{7} \mathrm{cel} / \mathrm{ml}\right)$ were added to the wells. The plate was incubated at $37^{\circ} \mathrm{C}$ and $5 \% \mathrm{CO}_{2}$ for $20 \mathrm{~min}$. The fluid was aspirated and the culture wells were washed three times with M199. After the last wash, 1 $\mathrm{N} \mathrm{NaOH}$ was added to the wells and the radioactivity of the fluids was measured by a $\gamma$-counter.

\section{Evaluation of the effect of test drugs}

The effect of test drugs was evaluated at 5 or 15 days after the anti-GBM serum injection.

The inhibitory percentage was calculated as follows: Inhibitory percentage $(\%)=$ (nephritic control

- test drug) $\times 100 /$ (nephritic control-normal).

\section{Statistical analyses}

The data represent means \pm S.D. or means \pm S.E., and the results were statistically evaluated by ANOVA. When these results were parametric, they were statistically evaluated by Duncan multiple-range test. When the results were non-parametric, they were statistically evaluated by the Kruskal-Wallis test.

\section{RESULTS}

\section{Urinary protein excretion (Table 1)}

At 15 days after the anti-GBM serum injection, the nephritic control rats exhibited severe proteinuria. Acteoside at $30 \mathrm{mg} / \mathrm{kg} /$ day, p.o. and cyclosporin $A$ at 20 $\mathrm{mg} / \mathrm{kg} /$ day, p.o. markedly suppressed the protein excretion by $56 \%$ and $73 \%$, respectively.

Glomerular accumulation of $L F A-1$ positive cells and up-regulation of ICAM-1 in glomeruli (Figs. 1 and 2)

At 5 and 15 days after the anti-GBM serum injection, the number of LFA-1-positive cells and ICAM-1 expression in glomeruli was markedly greater in nephritic control rats than in normal animals. Acteoside markedly suppressed the increase of LFA-1-positive cells on both the 5 th and 15 th days by $71 \%$ to $59 \%$ and the up-regulation of ICAM- 1 on the 15 th day by $66 \%$. Cyclosporin A suppressed the increase in LFA-1 positive cells on both
Table 1. Effects of acteoside and cyclosporin A on urinary protein excretion in crescentic-type anti-GBM nephritis in rats

\begin{tabular}{lc}
\hline Groups & Proteinuria (mg/day) \\
\hline Normal & $10.1 \pm 0.5$ \\
Nephritis & $233.1 \pm 99.9$ \\
Nephritis + Acteoside (30 mg/kg, p.o.) & $108.6 \pm 77.4^{*}$ \\
Nephritis + Cyclosporin A (20 mg/kg, p.o.) & $69.5 \pm 40.4^{* *}$ \\
\hline
\end{tabular}

Test drugs were given p.o. daily throughout the period of $1-15$ days after the anti-GBM serum injection. Proteinuria were determined 15 days after anti-GBM serum injection. Results are each reported as the mean \pm S.D. of 5 rats. ${ }^{*} \mathrm{P}<0.05,{ }^{* *} \mathrm{P}<0.01$, compared to the nephritic control.

days 5 and 15 by $>80 \%$ and completely suppressed the up-regulation of ICAM-1 on the 15th day.

ICAM-I expression on HUVECs in response to cytokines and PMA is inhibited by acteoside

Endothelial ICAM-1 expression induced with TNF- $\alpha$ $(100 \mathrm{U} / \mathrm{ml})$ increased by $4 \mathrm{hr}$ and reached fivefold compared to the control level by $20 \mathrm{hr}$. When HUVECs were stimulated by $\mathrm{IL}-1 \hat{\beta} \quad(125 \mathrm{U} / \mathrm{ml})$, the expression of ICAM-1 reached approx. threefold compared to the control. Treatment by PMA $(100 \mathrm{ng} / \mathrm{ml})$ resulted in an induction of ICAM-1 that peaked at $4 \mathrm{hr}$ and then diminished over the course of $72 \mathrm{hr}$ to levels approaching basal expression on unstimulated HUVECs (Table 2A). Moreover, anti-TNF polyclonal antibody excluded ICAM-1 expression on HUVECs in response to TNF- $\alpha$, not but anti-IL-1 polyclonal antibody (data not shown).

As shown in Fig. 3, acteoside prevented ICAM-1 expression of HUVECs in response to TNF- $\alpha(20 \mathrm{hr}), \mathrm{IL}-1 \beta$ $(20 \mathrm{hr})$ or PMA $(4 \mathrm{hr})$ at nontoxic concentration. When HUVECs were stimulated by TNF- $\alpha$ for 4 or $12 \mathrm{hr}$, the treatment with acteoside resulted in similar inhibition of ICAM-1 expression (data not shown). H-7, staurosporin and genistein prevented TNF- $\alpha$ - and PMA-induced ICAM-1 expression on HUVECs (Table 3). On the other hand, cyclosporin A and FK506 did not inhibit the up-regulation of ICAM-1 expression on HUVECs in response to TNF- $\alpha$ (Table 3 ).

ICAM-1 expression on mesangial cells in response to TNF- $\alpha$ is inhibited by acteoside (Fig. 4)

Cultured mesangial cells were analyzed by cell ELISA with anti-rat ICAM-1 mAb. ICAM-1 expression was observed on mesangial cells under the basal condition (O.D.: $0.124 \pm 0.007$ ). To study the kinetics of ICAM-1 expression, we stimulated mesangial cells with rat-TNF- $\alpha$ $(100 \mathrm{U} / \mathrm{ml})$ for $4,12,24$ or $48 \mathrm{hr}$. Stimulation of mesangial cells with TNF- $\alpha$ produced a rapid and near maximal 

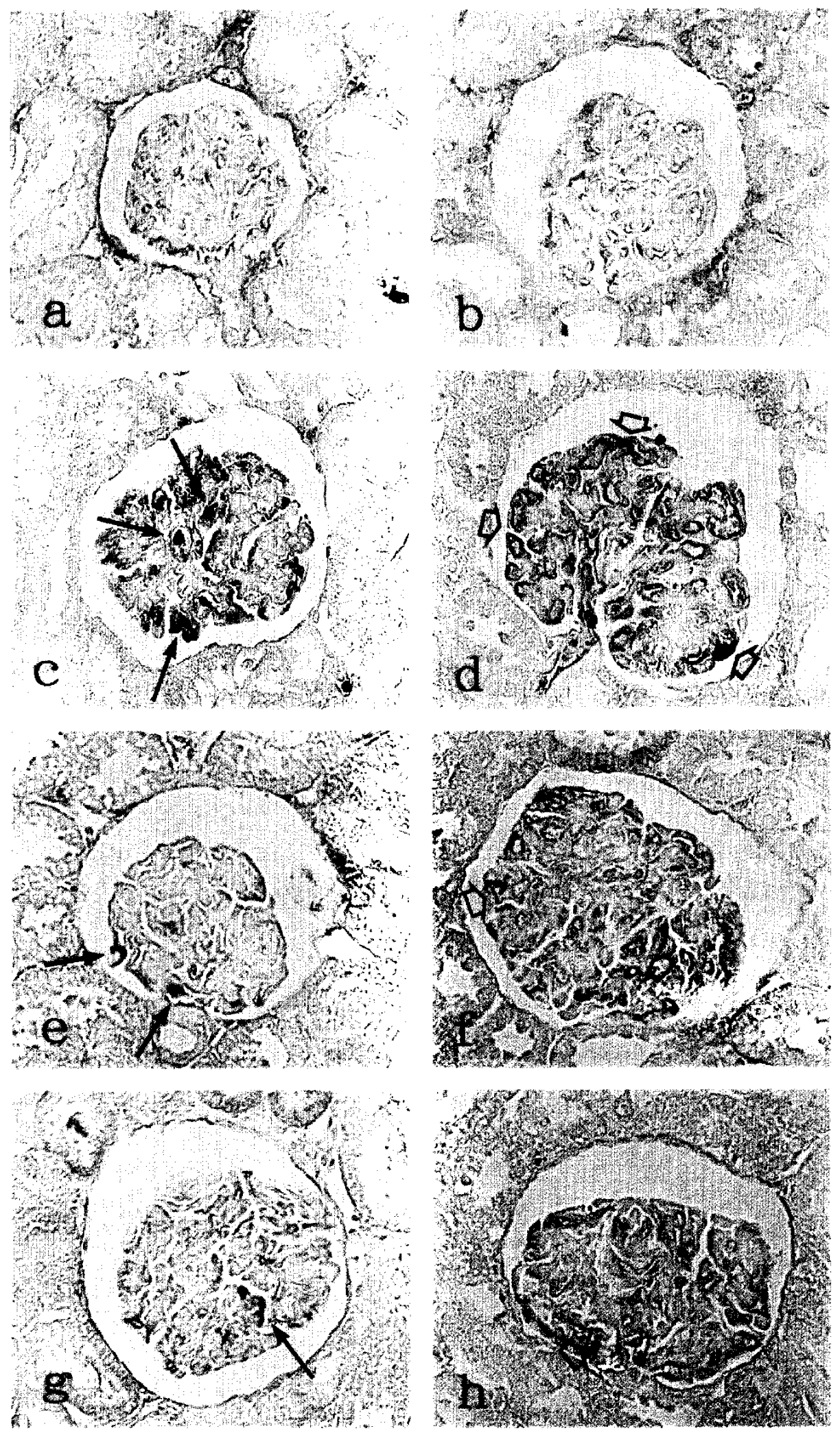

Fig. 1. Photographs of glomeruli immunohistochemically stained with anti-LFA-1 (a, c, e, g) or anti-ICAM-1 (b, d, f, h) monoclonal antibodies. Glomeruli were obtained 15 days after i.v. injection of anti-GBM serum. a and b: normal; $c$ and d: nephritic control; e and f: acteoside, $30 \mathrm{mg} / \mathrm{kg} /$ day, p.o.; g and h: cyclosporin A, $20 \mathrm{mg} / \mathrm{kg} / \mathrm{day}$, p.o. $\rightarrow$ indicates LFA-1positive cells $(c, e, g) . \Rightarrow$ indicates glomerular endothelial and mesangial localization of ICAM-1 $(d, f, h)$. Original magnification is $\times 400$. 
ICAM-1

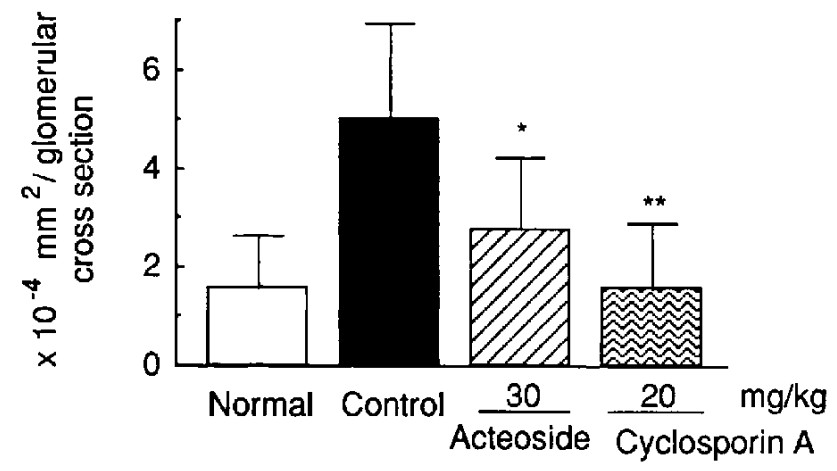

LFA-1-positive cell

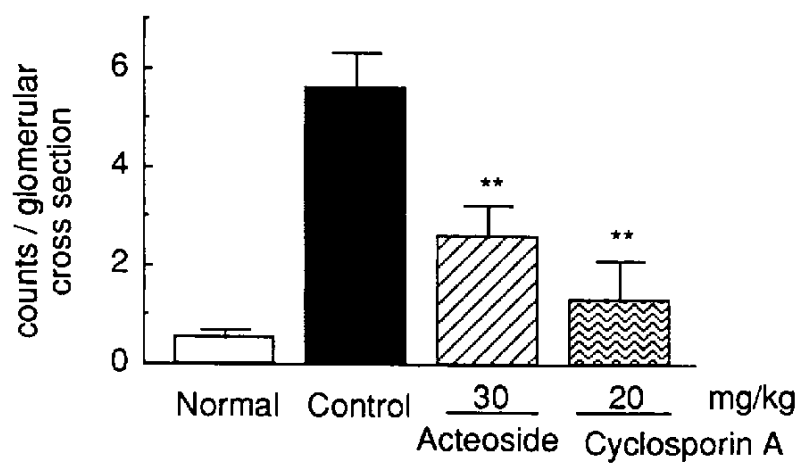

Fig. 2. Effects of acteoside and cyclosporin A on the ICAM-1 expression and the accumulation of LFA-1-positive cells in glomeruli of rats with crescentic-type anti-GBM nephritis. Test drugs were given p.o. daily throughout the period of $1-15$ days after the anti-GBM serum injection. ICAM-1 expression and LFA-1-positive cells were analyzed 15 days after the anti-GBM serum injection. Each column denotes the mean \pm S.D. of 5 rats. ${ }^{*} \mathrm{P}<0.05$, ${ }^{* *} \mathrm{P}<0.01$, compared to the nephritic control.

Table 2. Time course of endothelial ICAM-I (A) and VCAM-1 (B) expression in response to inflammatory stimuli and phorbol esters

\begin{tabular}{lccccc}
\hline A. & \multicolumn{5}{c}{ ICAM-1 expression [O.D.: 490 nm] } \\
\cline { 2 - 5 } Groups & $4 \mathrm{hr}$ & $12 \mathrm{hr}$ & $20 \mathrm{hr}$ & $48 \mathrm{hr}$ & $72 \mathrm{hr}$ \\
\cline { 2 - 6 } Non-stimulation & $0.075 \pm 0.017$ & $0.102 \pm 0.023$ & $0.142 \pm 0.070$ & - & - \\
TNF- $\alpha$ stimulation & $0.190 \pm 0.048^{* *}$ & $0.432 \pm 0.084^{* *}$ & $0.472 \pm 0.210^{* *}$ & - & - \\
IL-1 $\hat{\beta}$ stimulation & - & - & $0.382 \pm 0.085^{* *}$ & - & - \\
Non-stimulation & $0.099 \pm 0.011$ & $0.112 \pm 0.027$ & $0.142 \pm 0.002$ & $0.114 \pm 0.002$ & $0.114 \pm 0.002$ \\
PMA stimulation & $0.340 \pm 0.033^{* *}$ & $0.287 \pm 0.056^{* *}$ & $0.225 \pm 0.008^{* *}$ & $0.146 \pm 0.010$ & $0.124 \pm 0.004$ \\
\hline B. & & VCAM-1 expression [O.D.: $490 \mathrm{~nm}]$ & \\
Group & $0 \mathrm{hr}$ & $4 \mathrm{hr}$ & $12 \mathrm{hr}$ & $24 \mathrm{hr}$ & $36 \mathrm{hr}$ \\
\hline TNF- $\alpha$ stimulation & $0.138 \pm 0.024$ & $0.236 \pm 0.010^{* *}$ & $0.439 \pm 0.070^{* *}$ & $0.558 \pm 0.020^{* *}$ & $0.438 \pm 0.043^{* *}$ \\
\hline
\end{tabular}

A: HUVECs were treated continuously with TNF- $\alpha(100 \mathrm{U} / \mathrm{ml}), \mathrm{IL}-1 \beta(125 \mathrm{U} / \mathrm{ml})$ or PMA $(100 \mathrm{ng} / \mathrm{ml})$ for various periods of time, and ICAM-1 expression was determined by cell ELISA. B: HUVECs were treated continuously with TNF- $\alpha(100 \mathrm{U} / \mathrm{ml})$ for various periods of time, and VCAM- 1 expression was determined by cell ELISA. Results are expressed as means \pm S.E. of the optical density $(490 \mathrm{~nm})$ of $3-4$ experiments. ${ }^{* *} \mathrm{P}<0.01$, compared to the unstimulated HUVECs.

increase in ICAM-1 surface expression within $4 \mathrm{hr}$ (O.D.: $0.214 \pm 0.032$ ). Treatment of mesangial cells with TNF- $\alpha$ resulted in the induction of ICAM-1, which peaked at 24 $\mathrm{hr}$ and then diminished over the course of $48 \mathrm{hr}$ (data not shown). Further evidence that acteoside is responsible for inhibition of ICAM-1 expression was provided by the observations that acteoside inhibited TNF- $\alpha$-mediated induction of ICAM-1 on cultured mesangial cells. The ability of acteoside to block TNF- $\alpha$-induced expression of ICAM-1 was concentration-dependent, becoming apparent only at the level of $1 \times 10^{-5} \mathrm{M}$, and $\mathrm{H}-7\left(1 \times 10^{-5}\right.$ and $1 \times 10^{-6} \mathrm{M}$ ) also inhibited TNF- $\alpha$-mediated induction of ICAM-1 expression.
ELAM-1 and VCAM-1 expressions on HUVECS in response to $T N F-\alpha$ are not inhibited by acteoside

ELAM-1 and VCAM-1 expressions on the surface of HUVEC monolayers stimulated with TNF- $\alpha(100 \mathrm{U} / \mathrm{ml})$ for 4,12 or $20 \mathrm{hr}$ were measured by cell ELISA. In the continuous presence of TNF- $\alpha$, surface expression of HUVEC ELAM-1 peaked at $4 \mathrm{hr}$ and VCAM-1 reached maximum levels by $12-20 \mathrm{hr}$ (Table 2B).

Acteoside failed to abrogate TNF- $\alpha$-induced ELAM- 1 and VCAM-1 expressions on the surface of HUVECs at nontoxic concentrations (Table 4). On the other hand, $\mathrm{H}$ 7 and genistein significantly reduced TNF- $\alpha$-induced ICAM-1 expression of HUVECs, decreasing agonist- 


\section{HUVECS}

TNF- $\alpha$ stimulation

IL-1 $\beta$ stimulation

PMA stimulation
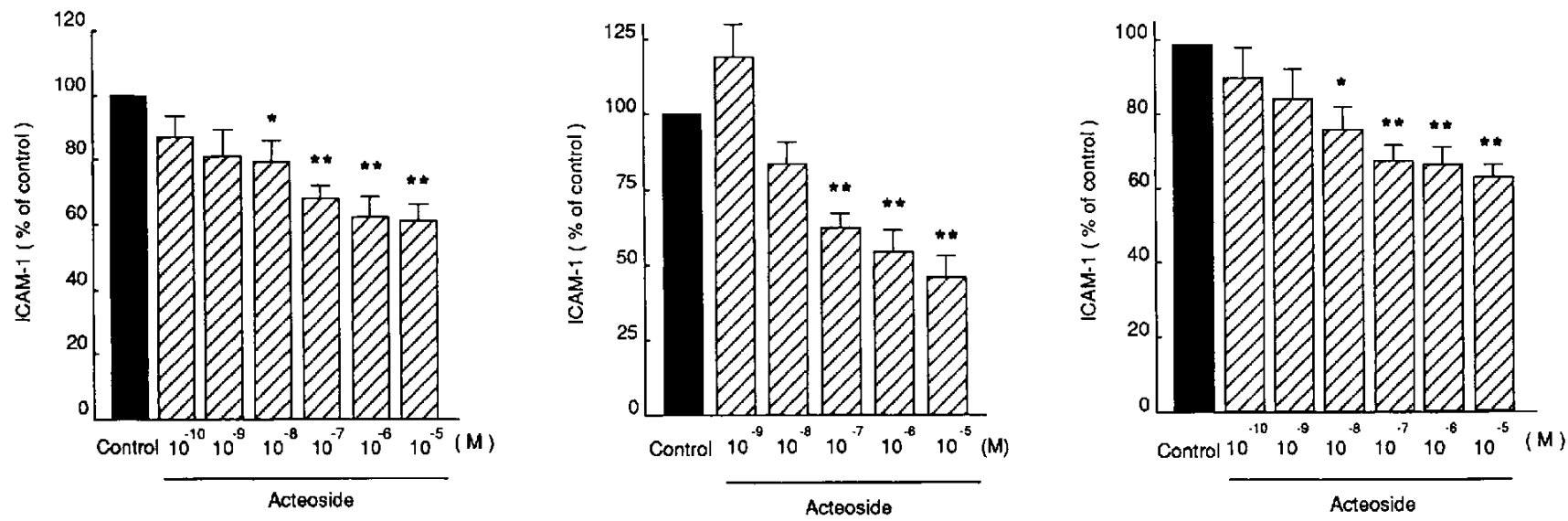

Fig. 3. Effect of acteoside on endothelial ICAM-1 expression induced by TNF- $\alpha$, IL-1 $\beta$ or PMA. HUVECs were stimulated with TNF- $\alpha(100 \mathrm{U} / \mathrm{ml}, 20 \mathrm{hr}), \mathrm{IL}-1 \beta(125 \mathrm{U} / \mathrm{ml}, 20 \mathrm{hr})$ or PMA $(100 \mathrm{ng} / \mathrm{ml}, 4 \mathrm{hr})$ in the absence or presence of acteoside. ICAM-1 expression was determined by cell ELISA. Results are reported as a percentage with respect to the expression induced by each activator in the absence of acteoside and are means \pm S.E. of $5-15$ experiments. ${ }^{*} \mathrm{P}<0.05,{ }^{* *} \mathrm{P}<0.01$, compared to TNF- $\alpha$, IL- $1 \beta$ or PMA stimulation (control).

Table 3. Effects of kinase inhibitors and immunosuppressive agents on endothelial ICAM-1 expression induced by TNF- $\alpha$ or PMA

\begin{tabular}{lrc}
\hline Treatment & Percent of control & $\begin{array}{c}\text { Significance } \\
\text { (P value) }\end{array}$ \\
\hline TNF- $\alpha(100 \mathrm{U} / \mathrm{ml})$ & $100.0 \pm 0.0$ & \\
TNF- $\alpha+\mathrm{H}-7\left(1 \times 10^{-7} \mathrm{M}\right)$ & $74.6 \pm 3.8$ & $<0.05$ \\
TNF- $\alpha+\mathrm{H}-7\left(1 \times 10^{-6} \mathrm{M}\right)$ & $77.2 \pm 5.1$ & $<0.05$ \\
TNF- $\alpha+$ H-7 $\left(1 \times 10^{-5} \mathrm{M}\right)$ & $46.8 \pm 6.7$ & $<0.01$ \\
TNF- $\alpha+$ Staurosporin $\left(1 \times 10^{-9} \mathrm{M}\right)$ & $65.2 \pm 6.9$ & $<0.01$ \\
TNF- $\alpha+$ Staurosporin $\left(1 \times 10^{-8} \mathrm{M}\right)$ & $61.6 \pm 11.1$ & $<0.01$ \\
TNF- $\alpha+$ Staurosporin $\left(1 \times 10^{7} \mathrm{M}\right)$ & $36.0 \pm 10.3$ & $<0.01$ \\
TNF- $\alpha+$ Genistein $\left(1 \times 10^{-7} \mathrm{M}\right)$ & $81.4 \pm 3.1$ & $\mathrm{NS}$ \\
TNF- $\alpha+$ Genistein $\left(1 \times 10^{-6} \mathrm{M}\right)$ & $79.7 \pm 2.8$ & $<0.05$ \\
TNF- $\alpha+$ Genistein $\left(1 \times 10^{-5} \mathrm{M}\right)$ & $71.1 \pm 4.4$ & $<0.05$ \\
TNF- $\alpha+$ Genistein $\left(1 \times 10^{-4} \mathrm{M}\right)$ & $50.5 \pm 2.7$ & $<0.01$ \\
TNF- $\alpha+$ FK $506\left(1 \times 10^{-5} \mathrm{M}\right)$ & $102.4 \pm 12.6$ & $\mathrm{NS}$ \\
TNF- $\alpha+$ Cyclosporin A $\left(1 \times 10^{-5} \mathrm{M}\right)$ & $93.3 \pm 6.0$ & $\mathrm{NS}$ \\
PMA $(100$ ng $/ \mathrm{ml})$ & $100.0 \pm 0.0$ & \\
PMA + H-7 $\left(1 \times 10^{-7} \mathrm{M}\right)$ & $70.8 \pm 15.8$ & $<0.05$ \\
PMA + H-7 $\left(1 \times 10^{-6} \mathrm{M}\right)$ & $57.2 \pm 11.5$ & $<0.01$ \\
PMA + H-7 $\left(1 \times 10^{-5} \mathrm{M}\right)$ & $42.1 \pm 7.4$ & $<0.01$ \\
PMA +Genistein $\left(1 \times 10^{-6} \mathrm{M}\right)$ & $84.0 \pm 5.6$ & $\mathrm{NS}$ \\
PMA +Genistein $\left(1 \times 10^{-5} \mathrm{M}\right)$ & $78.0 \pm 5.0$ & $<0.05$ \\
PMA + Genistein $\left(1 \times 10^{4} \mathrm{M}\right)$ & $67.8 \pm 4.2$ & $<0.01$ \\
\hline
\end{tabular}

HUVECs were stimulated with TNF- $\alpha(100 \mathrm{U} / \mathrm{ml}, 20 \mathrm{hr})$ or PMA $(100 \mathrm{ng} / \mathrm{ml}, 4 \mathrm{hr})$ in the absence or presence of H-7, staurosporin, genistein, FK506 or cyclosporin A. ICAM-1 expression was determined by cell ELISA. Results are each expressed as a percentage of the expression induced by TNF- $\alpha$ in the absence of agents and are means $\pm S$.E. of $5-15$ experiments. NS: not significant. 


\section{Mesangial cell}

Acteoside

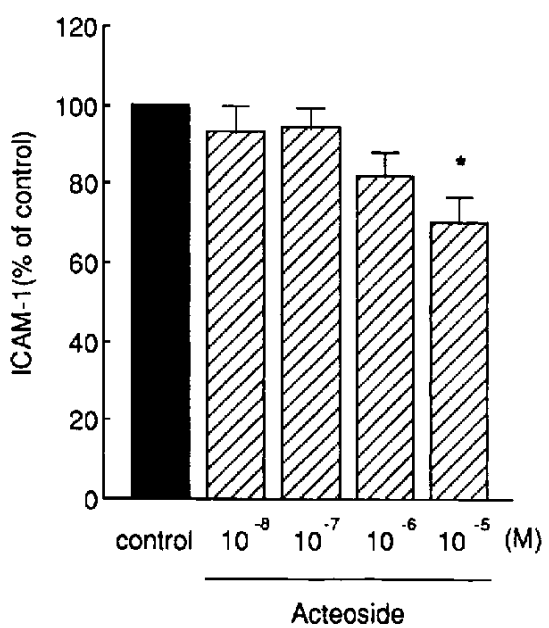

H-7

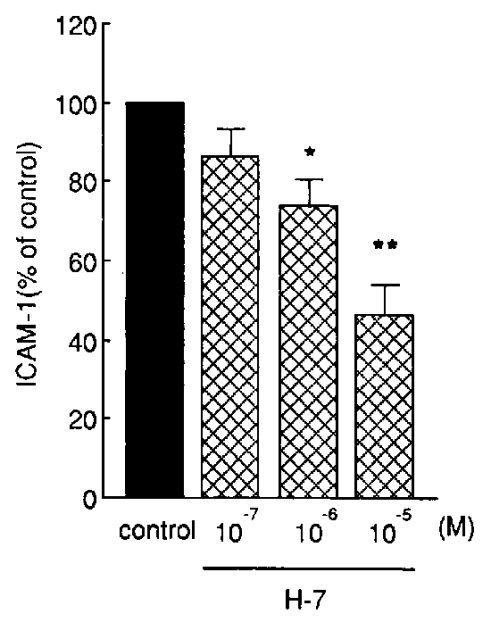

Genistein

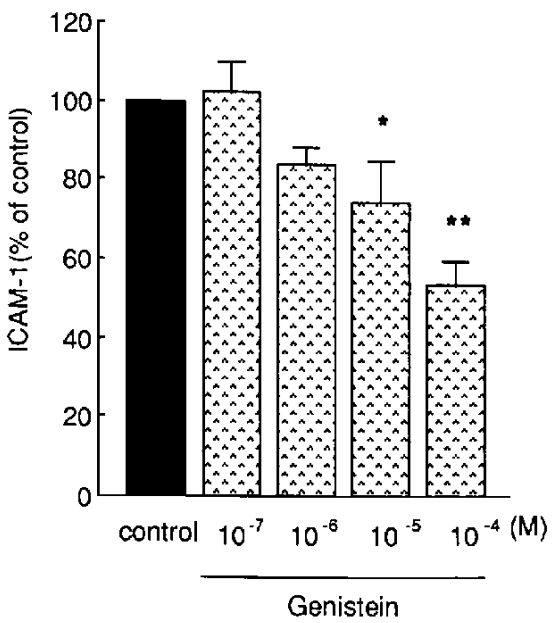

Fig. 4. Effects of acteoside, H-7 and genistein on mesangial ICAM-1 expression induced by TNF- $\alpha$. Mesangial cells were stimulated with rat TNF- $\alpha(100 \mathrm{U} / \mathrm{ml}, 20 \mathrm{hr})$ in the absence or presence of these drugs. ICAM-1 expression was determined by cell ELISA. Results are reported as a percentage with respect to the expression induced by each activator in the absence of agents and are means \pm S.E. of 5 experiments. ${ }^{*} \mathbf{P}<0.05,{ }^{* *} \mathbf{P}<0.01$, compared to $\mathrm{TNF}-\alpha$ stimulation (control).

Table 4. Effects of acteoside and kinase inhibitors on endothelial ELAM-1 or VCAM-1 expression induced by TNF- $\alpha$

\begin{tabular}{lcc}
\hline Treatment & Percent of contol & $\begin{array}{c}\text { Singificance } \\
\text { (P value) }\end{array}$ \\
\cline { 1 - 2 } ELAM-1 expression & & \\
TNA- $\alpha(100 \mathrm{U} / \mathrm{ml})$ & $100.0 \pm 0.0$ & NS \\
TNA- $\alpha+$ Acteoside $\left(1 \times 10^{-7} \mathrm{M}\right)$ & $98.9 \pm 12.9$ & NS \\
TNA- $\alpha+$ Acteoside $\left(1 \times 10^{-6} \mathrm{M}\right)$ & $98.5 \pm 13.1$ & NS \\
TNA- $\alpha+$ Acteoside $\left(1 \times 10^{-5} \mathrm{M}\right)$ & $92.4 \pm 5.3$ & NS \\
TNA- $\alpha+$ H-7 $\left(1 \times 10^{-7} \mathrm{M}\right)$ & $76.8 \pm 5.3$ & $<0.05$ \\
TNA- $\alpha+$ H-7 $\left(1 \times 10^{-6} \mathrm{M}\right)$ & $73.2 \pm 1.3$ & $<0.01$ \\
TNA- $\alpha+$ H-7 $\left(1 \times 10^{-5} \mathrm{M}\right)$ & $57.3 \pm 1.3$ & $<0.05$ \\
TNA- $\alpha+$ Genistein $\left(1 \times 10^{-7} \mathrm{M}\right)$ & $67.0 \pm 14.7$ & $<0.01$ \\
TNA- $\alpha+$ Genistein $\left(1 \times 10^{-6} \mathrm{M}\right)$ & $47.6 \pm 21.1$ & $<0.01$ \\
TNA- $\alpha+$ Genistein $\left(1 \times 10^{-5} \mathrm{M}\right)$ & $44.4 \pm 12.2$ & $<0.01$ \\
TNA- $\alpha+$ Genistein $\left(1 \times 10^{-4} \mathrm{M}\right)$ & $15.3 \pm 8.9$ & \\
VCAM-1 expression & & NS \\
TNF- $\alpha(100 \mathrm{U} / \mathrm{ml})$ & $100.0 \pm 0.0$ & $\mathrm{NS}$ \\
TNF- $\alpha+$ Acteoside $\left(1 \times 10^{-7} \mathrm{M}\right)$ & $121.5 \pm 14.6$ & $\mathrm{NS}$ \\
TNF- $\alpha+$ Acteoside $\left(1 \times 10^{-6} \mathrm{M}\right)$ & $128.9 \pm 10.0$ & $\mathrm{NS}$ \\
TNF- $\alpha-$ Acteoside $\left(1 \times 10^{-5} \mathrm{M}\right)$ & $136.3 \pm 15.7$ & $\mathrm{NS}$ \\
TNF- $\alpha+\mathrm{H}-7\left(1 \times 10^{-7} \mathrm{M}\right)$ & $91.0 \pm 6.3$ & \\
TNF- $\alpha+\mathrm{H}-7\left(1 \times 10^{-6} \mathrm{M}\right)$ & $91.7 \pm 15.0$ & \\
TNF- $\alpha+\mathrm{H}-7\left(1 \times 10^{-5} \mathrm{M}\right)$ & $49.0 \pm 13.2$ & \\
\hline
\end{tabular}

HUVECs were stimulated with TNF- $\alpha(100 \mathrm{U} / \mathrm{ml}, 4$ or $12 \mathrm{hr})$ in the absence or presence of acteoside, H-7 or genistein. ELAM-1 or VCAM-1 expression was determined by cell ELISA. Results are each expressed as a percentage of the expression induced by TNF$\alpha$ in the absence of agents and are means \pm S.E. of 5-10 experiments. NS: not significant. 


\section{PMNs}

Acteoside

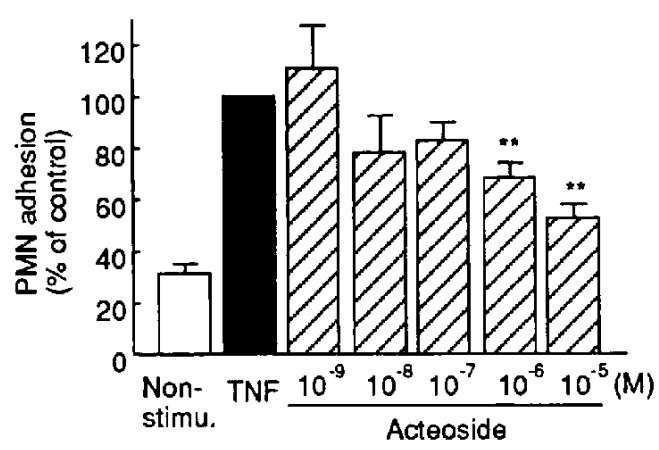

$H-7$

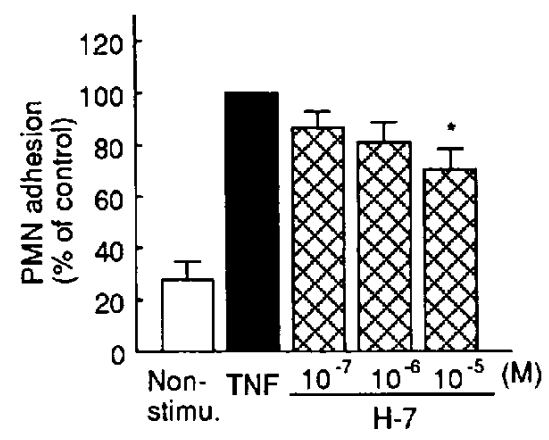

Cyclosporin A

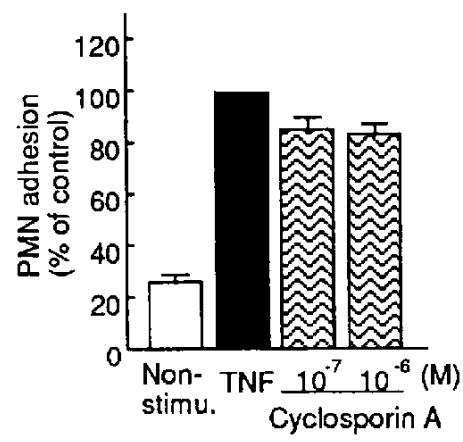

\section{Macrophages}

Acteoside

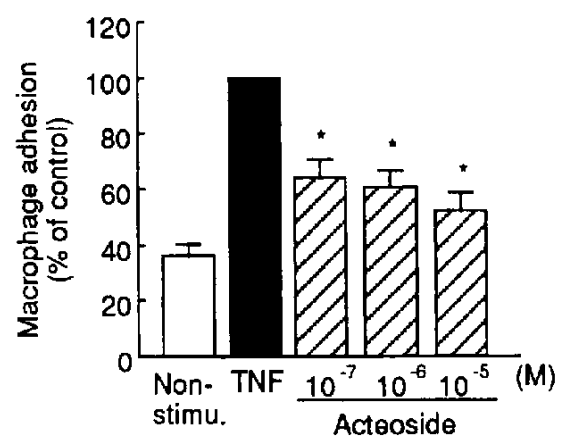

$\mathrm{H}-7$

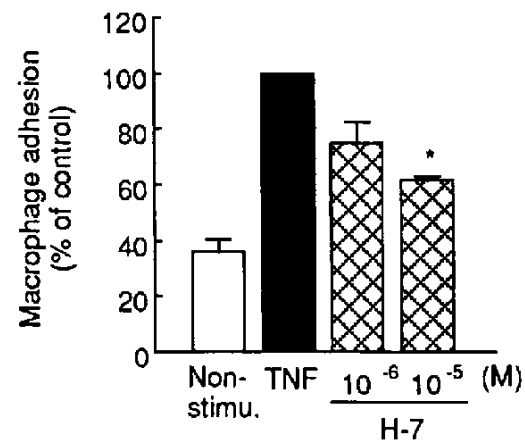

Fig. 5. Effects of acteoside, H-7 and cyclosporin A on the adhesion of neutrophils (PMNs) and macrophages to TNF- $\alpha$ stimulated HUVECs. HUVEC monolayers were incubated with medium alone, TNF- $\alpha(100 \mathrm{U} / \mathrm{ml})$ or TNF- $\alpha+$ the drug for $4 \mathrm{hr}$; Then the medium was exchanged, ${ }^{51} \mathrm{Cr}$-labeled PMNs or macrophages were added above the activated or inactivated HUVECs, and they were incubated for $20 \mathrm{~min}$ at $37^{\circ} \mathrm{C}$ in $5 \% \mathrm{CO}_{2}$. The data are means \pm S.E. of 6 experiments. ${ }^{*} \mathrm{P}<0.05,{ }^{* *} \mathrm{P}<0.01$, compared to TNF- $\alpha$ stimulation (control).

induced ICAM-1 expression by 30-50\% (Table 4).

Acteoside inhibits PMN and macrophage adhesion to HUVECS stimulated by $T N F-\alpha$ (Fig. 5 )

Acteoside $\left(1 \times 10^{-5}\right.$ and $\left.1 \times 10^{-6} \mathrm{M}\right)$ inhibited the adhesion of PMNs to HUVECs stimulated by TNF- $\alpha$ by $40 \%$ and $68 \%$, respectively. Moreover, in the adhesion of macrophages to HUVECs stimulated by TNF- $\alpha$, acteoside markedly inhibited it in a dose-dependent manner. H-7 also inhibited the adhesion of PMNs and macrophages to activated HUVECs. Anti-ICAM-1 mAb markedly suppressed the adhesion of PMNs to HUVECs stimulated by TNF- $\alpha$ (data not shown). Moreover when PMNs were treated with anti-LFA-1, Mac-1 or VLA-4 $\mathrm{mAb}$, the adhesion was significantly suppressed by about $50 \%$ (data not shown). However, cyclosporin A failed to inhibit the adhesion of PMNs and macrophages to HUVECs stimulated by TNF- $\alpha$.

Acteoside did not inhibit solubilization of ICAM-1 nor the binding of anti-ICAM-1 $m A$ b to ICAM-I protein

Determination of soluble-ICAM-1 (s-ICAM-1) in the culture medium of TNF- $\alpha$-stimulated HUVECs by an ICAM-1 test kit (T Cell Diagnostics, Inc., Cambridge, MA, USA) indicated that acteoside, $\mathrm{H}-7$ and cyclosporin A failed to increase s-ICAM-1 in the culture medium (data not shown). Moreover, acteoside did not inhibit the binding of anti-ICAM-1 monoclonal antibody to standard ICAM-1 protein (data not shown). 


\section{DISCUSSION}

Our previous study demonstrated that acteoside suppressed the urinary protein excretion and histological changes including crescent formation when nephritic rats were treated with acteoside from 1 or 20 days after induction of crescentic-type anti-GBM nephritis and also suppressed the accumulation of CD4-positive cells, CD8positive cells and IL-2-receptor-positive cells (activated T cells) in the glomeruli of rats with crescentic-type antiGBM nephritis $(9,10)$. The role of leukocytes in the induction and/or progression of anti-GBM antibody-induced nephritis in rats has been well-established (14). The inhibition of induction of glomerulonephritis by the depletion of leukocytes suggests that leukocytes may be one of the main factors in the induction of glomerular diseases (15-17). It has been well-demonstrated that cyclosporin A (18, 19), FK506 (20) and 15-deoxyspergualin $(21,22)$, which have immunosuppressive actions, are effective on a variety of glomerular diseases. These findings suggest that the cell-mediated immune response plays an important role in the induction and progression of crescentic-type anti-GBM nephritis in rats. In addition, the decrease in glomerular leukocytes in nephritic rats may block the induction and progression of this disease. Therefore, the antinephritic action of acteoside on crescentic-type anti-GBM nephritis may be due to the suppression of the accumulation of leukocytes in glomeruli. However, in an in vitro study, acteoside failed to inhibit IL-2 production in mouse spleen cells stimulated by ConA and basal $\mathrm{LTB}_{4}$ production from nephritic glomeruli ( $K$. Hayashi et al., unpublished data). Therefore, it was considered that acteoside inhibited the accumulation of leukocytes in glomeruli by a mechanism different from those of cyclosporin A and FK506.

Recently, with respect to the development of experimental and human nephritis, the up-regulation of ICAM-1 and VCAM-1 expression was observed in glomeruli and proximal tubules $(7,23,24)$, and antibody against adhesion molecules suppressed the urinary protein through a reduction in the glomerular influx of neutrophils $(5,6)$. Moreover, it is considered that superoxide anion and protease, which are released by leukocytes, injure an inflamed tissue, including nephritic glomeruli, when leukocytes adhere to endothelial cells through the binding of integrin family proteins to immunoglobulin superfamily proteins $(25-27)$. In this in vivo study, acteoside inhibited the accumulation of LFA-1-positive cells and the up-regulation of ICAM-1 expression in nephritic glomeruli (Figs. 1 and 2). This result suggests that acteoside suppresses the accumulation leukocytes in nephritic glomeruli through the inhibition of ICAM-1 expression. In the further investigation to clarify the effect of acteoside on the expression of adhesion molecules including ICAM-1, HUVECs and cultured rat mesangial cells were treated with acteoside in the presence of TNF$\alpha, I L-1 \beta$ or PMA. Acteoside decreased the amount of ICAM-1 expression on HUVECs and mesangial cells in response to inflammatory cytokines or PMA (Figs. 3 and 4), but not VCAM-1 and ELAM-1 expression in the in vitro studies (Table 4). Moreover, acteoside inhibited the adhesion of neutrophils and macrophages to HUVECs in response to TNF- $\alpha$ (Fig. 5). These results indicate that acteoside suppresses the adhesion of leukocytes to endothelial cells through the inhibition of ICAM-1 expression.

The in vitro adhesion assay was performed using HUVECs and rat PMNs or macrophages. We considered the possibility that rat PMNs and macrophages could adhere to HUVECs via some factor other than adhesion molecules. However, the adhesion of rat PMNs and macrophages to HUVECs was suppressed when HUVECs were treated with anti-human ICAM-1 mAb and PMNs treated with anti-rat LFA-1, Mac-1 or VLA-4 mAb (data not shown). Therefore, these results suggest that this adhesion depends on the leukocyte-endothelium interaction through these adhesion molecules.

On the other hand, cyclosporin A (Figs. 1 and 2) and FK506 (data not shown) suppressed the up-regulation of glomerular ICAM-1 expression in anti-GBM nephritic rats. However, cyclosporin A and FK506 could not prevent inflammatory cytokine-mediated up-regulation of ICAM-1 expression on the surface of HUVECs. Yard et al. (28) reported that cyclosporin A and FK506 inhibited TNF- $\alpha$ production by cultured human proximal tubular cells in response to IL-1 $\alpha$. In other studies by Nguyen et al. (29), cyclosporin A was shown to inhibit TNF- $\alpha$ production in monocytes. Several reports have demonstrated that TNF- $\alpha$ is produced by intrinsic glomerular cells $(30,31)$ and participates in the recruitment of inflammatory cells in the glomeruli and in the progression of nephritis. Therefore, it has been considered that the decline in glomerular ICAM-1 expression was associated with an inhibition of $\mathrm{TNF}-\alpha$ production in rats treated with cyclosporin A.

Recently, in TNF signal transduction for ICAM-1 expression, it has been reported that TNF- $\alpha$-induced expressions of ICAM-1 and VCAM- 1 are linked to protein kinase $C$ (PKC) activation $(32,33)$, and PKC activation can induce the ICAM-1 mRNA expression in endothelial cells (34). In our present studies and another report (35), PKC inhibitors, $\mathrm{H}-7$ and staurosporin suppressed TNF$\alpha$-induced ICAM-1, VCAM-1 and ELAM-1 expression on the surface of HUVECs (Tables 3 and 4) and stimulation of HUVECs with PMA resulted in the induction of ICAM-1 (Table 3). Myers et al. (34) have been reported 
that TNF- $\alpha$ can induce ICAM-1 on HUVECs, whose PKC was already down-regulated with PMA. These results suggest that there is a PKC-mediated pathway and an alternative pathway in the signal transduction for ICAM-1 expression with TNF- $\alpha$. Moreover, a tyrosine kinase inhibitor, genistein, suppressed the up-regulation of ICAM- 1 expression stimulated by TNF- $\alpha$ or PMA (Table 3). Liebenhoff et al. (36) demonstrated that c-src, tyrosine kinase, is phosphorylated by PKC in human platelets. It is reported that tyrosine phosphorylation of multiple proteins is stimulated by PMA in human mesangial cells (37). These findings suggest that there is src downstream of PKC in the signal transduction for ICAM-1 expression. Therefore, src may mediate signaling for ICAM-1 expression from the TNF receptor and PKC.

On the other hand, the up-regulation of ICAM-1 expression in response to TNF- $\alpha$ or PMA was reduced by acteoside (Fig. 3). However, acteoside failed to abrogate the TNF- $\alpha$-induced VCAM- 1 and ELAM-1 expression on the surface of HUVECs (Table 4). Furthermore, acteoside did not increase the amount of S-ICAM-1 in the culture medium of TNF- $\alpha$-treated HUVECs (data not shown), although it is reported that s-ICAM-1 is shed from the cell surface into culture medium in a dose- and time-dependent manner (38). Acteoside did not affect the binding of ICAM-1 mAb to ICAM-1 protein (data not shown). It has been speculated that acteoside exerts suppression downstream of PKC in TNF-receptor signal transduction and/or translation of ICAM-1 protein from the mRNA.

We reported (9) that acteoside suppressed the development of anti-GBM nephritis as assessed by the clinical condition and histological changes. Furthermore, it has been suggested that the antinephritic effect of acteoside is mediated by the inhibition of leukocyte infiltration into nephritic glomeruli (10). In this study, we demonstrated that acteoside inhibited urinary protein excretion (Table 1) and the increase of ICAM-1 expression and the accumulation of LFA-1-positive cells in nephritic glomeruli (Figs. 1 and 2). Moreover, acteoside inhibited TNF- $\alpha$-induced ICAM-1 expression on the surface of HUVECs and mesangial cells and PMN and macrophage adhesion to TNF- $\alpha$-stimulated HUVECs in the in vitro studies (Figs. 3-5). Therefore, these findings suggest that the antinephritic action of acteoside is due to the reduced glomerular influx of leukocytes through the inhibition of leukocyte adhesion to glomerular endothelial cells. Although immunosuppressants, interleukin-1 receptor antagonist (39) and mAbs directed towards adhesion molecules including ICAM-1 $(5,6)$ may prevent leukocyte infiltration into the glomeruli and urinary protein excretion, renal dysfunction caused by cyclosporin $\mathrm{A}$ treatment
(40) and finding an appropriate administration route for a protein drug are some of the problems in the long term treatment with these agents. Acteoside may be a promising antinephritic agent, because it is effective in oral administration and does not imperil renal function.

\section{REFERENCES}

1 Rothlein $\mathbf{R}$ and Wegner C: Role of intercellular adhesion molecule-1 in inflammatory response. Kidney Int 41, 617-619 (1992)

2 Brady H: Leukocyte adhesion molecules and kidney disease. Kidney Int 45, 1285 - 1300 (1994)

3 Muller WA and Weigl A: Monocyte-selective transendothelial migration: Dissection of the binding and transmigration phases by an in vitro assay. J Exp Med 176, 819-828 (1992)

4 Isobe M, Yagita H, Okumuta $K$ and Ihara A: Specific acceptance of cardiac allograft after treatment with antibodies to ICAM-1 and LFA-1. Science 255, 1125-1127 (1992)

5 Mulligan MS, Johnson KJ, Todd RF III, Issekutz TB, Miyasaka M, Tamatani T, Smith CW, Anderson DC and Ward PA: Requirements for leukocyte adhesion molecules in nephrotoxic nephritis. J Clin Invest 91, 577-587 (1993)

6 Kawasaki K, Yaoita E, Yamamoto T, Tamatani T, Miyasaka $M$ and Kihara I: Antibodies against intercellular adhesion molecule-1 and lymphocyte function-associated antigen-1 prevent glomerular injury in rat experimental crescentic glomerulonephritis. J Immunol 150, 1074 - 1083 (1993)

7 Wuthrich RP, Jevnikar AM, Takei F, Glimcher LH and Kelley VE: Intercellular adhesion molecule-1 (ICAM-1) expression is up-regulated in autoimmune murine lupus nephritis. Am J Pathol 136, 441-450 (1990)

8 Canton AD, Fuiano G, Sepe V, Caglioti A and Ferrone S: Mesangial expression of intercellular adhesion molecule-1 in primary glomerulosclerosis. Kidney Int 41, 951-955 (1992)

9 Hayashi $K$, Nagamatsu T, Ito $M$, Hattori $T$ and Suzuki $Y$; Acteoside, a component of Stachys sieboldi MIQ, may be a promising antinephritic agent: Effect of acteoside on crescentictype anti-GBM nephritis in rats. Jpn J Pharmacol 65, 143-151 (1994)

10 Hayashi $\mathrm{K}$, Nagamatsu T, Ito $\mathrm{M}$, Hattori $\mathrm{T}$ and Suzuki $\mathrm{Y}$ : Acteoside, a component of Stachys sieboldi MIQ, may be a promising antinephritic agent (2): Effect of acteoside on leukocyte accumulation in the glomeruli of nephritic rats. Jpn J Pharmacol 66, 47 - 52 (1994)

11 Briscoe DM and Cotran RS: Role of leukocyte-endothelial cell adhesion molecules in renal inflammation: In vitro and in vivo studies. Kidney Int 44, S-27-S-34 (1993)

12 Nikolic-Paterson DJ, Yu Y and Atkins RC: Regulation of glomerular VCAM-1 and ELAM-1 gene expression by inflammatory stimuli (abstract). J Am Soc Nephrol 3, 639 (1992)

13 Kingsbury FB, Clark CP, Williams G and Post AL: The rapid determination of albumin in urine. J Lab Clin Med 11, 981 - 989 (1926)

14 Main IW, Nikolic-Paterson DJ and Atkins RC: T cells and macrophages and their role in renal injury. Semin Nephrol 12, $395-407$ (1992)

15 Matsumoto K: Production of interleukin-1 by glomerular macrophages in nephrotoxic serum nephritis. Am J Nephrol 10, 
$502-506(1990)$

16 Holdsworth SR and Neale TJ: Macrophage induced glomerular injury: Cell transfer studies in passive autologous antiglomerular basement membrane antibody-initiated experimental glomerulonephritis. Lab Invest 51, 172-180 (1984)

17 Holdsworth SR, Neal TJ and Wilson CB: Abrogation of macrophage-dependent injury in experimental glomerulonephritis in the rabbit. J Clin Invest 68, 686-698 (1988)

18 Neild GH, Ivory K and Williams DG: Cyclosporin A inhibits acute serum sickness in rabbits. Clin Exp Immunol 52, 586-594 (1983)

19 Nagamatsu T, Kojima N, Kondo N, Hattori T, Kojima R, Ito $\mathrm{M}$ and Suzuki $\mathrm{Y}$ : Suppression by cyclosporin A of anti-GBM nephritis in rats. Jpn J Pharmacol 58, 27-36 (1992)

20 Okubo Y, Tsukada Y, Maezawa A, Ono K, Yano S and Naruse T: FK506, a novel immunosuppressive agent, induces antigenspecific immunotolerance in active Heymann's nephritis and in the autologous phase of Masugi nephritis. Clin Exp Immunol 82, 450-455 (1990)

21 Okubo M, Inoue K, Umetani N, Sato N, Kamata K, Masaki Y, Uchiyama $T$, Yan $X$, Aoyagi $T$ and Shirai $T$ : Lupus nephropathy in New Zealand Fl hybrid mice treated by $(-) 15-$ deoxyspergualin. Kidney Int 54, 467-473 (1988)

22 Lan HY, Zarama M, Nikolic-Paterson DJ, Kerr PG and Atkins RC: Suppression of experimental crescentic glomerulonephritis by deoxyspergualin. J Am Soc Nephrol 3, 1765-1774 (1993)

23 Wuthrich RP and Snyder TL: Vascular cell adhesion molecule1 (VCAM-1) expression in murine lupus nephritis. Kidney Int 42, $903-914$ (1992)

24 Bruijn JA and Dinklo NACM: Distinct patterns of expression of intercellular adhesion molecule-1, vascular cell adhesion molecule-1, and endothelial-leukocyte adhesion molecule- 1 in renal disease. Lab Invest 69, 329-335 (1993)

25 Suranyi MG, Bishop GA, Clayberger C, Krensky AM, Leenaerts P, Aversa $G$ and Hall BM: Lymphocyte adhesion molecule in $\mathrm{T}$ cell-mediated lysis of human kidney cells. Kidney Int 39, 312-319 (1991)

26 Carla JV, Taylor CG, Riser B, Shumaker DK, Yeh K, Dame M, Gibbs DF, Todd RF III, Dumler F, Bromberg J and Killen PD: Mesangial cell killing by leukocytes: Role of leukocyte oxidants and proteolytic enzymes. Kidney Int 42, 1169-1177 (1992)

27 Romanic AM and Madri JA: The induction of $72-\mathrm{kD}$ gelatinase in T cells upon adhesion to endothelial cells is VCAM-1 dependent. J Cell Biol 125, 1165-1178 (1994)

28 Yard BA, Pancham RR, Paape ME, Daha MR, van Es LA and van der Woude FJ: CsA, FK506, corticosteroids and rapamycin inhibit $\mathrm{TNF} \alpha$ production by cultured PTEC. Kidney Int 44, $352-358$ (1993)
29 Nguyen DT, Eskandari MK, De Forge LE, Raiford CL, Strieter RM, Kunkel SL and Remick DG: Cyclosporin A modulation of tumor necrosis factor gene expression in vitro and in vivo. J Immunol 144, 3822-3828 (1990)

30 Egido J, Gómez-Chiarri M, Ortíz A, Bustos C, Alonso J, Gómez-Guerrero C, Gómez-Garre D, López-Armada MJ, Palaza $\mathbf{J}$ and Gonzalez E: Roll of tumor necrosis factor- $\alpha$ in the pathogenesis of glomerular diseases. Kidney Int 43, S-59-S-64 (1993)

31 Hasegawa G, Nakano K, Sawada M, Uno K, Shibayama Y, lenaga $\mathrm{K}$ and Kondo $\mathrm{M}$ : Possible role of tumor necrosis factor and interleukin- 1 in the development of diabetic nephropathy. Kidney Int 40, 1007-1012 (1991)

32 Mattila P, Majuri ML, Mattila PS and Renkonen R: TNF $\alpha$-induced expression of endothelial adhesion molecules, ICAM-1 and VCAM-1, is linked to protein kinase C activation. Scand $J$ Immunol 36, 159-165 (1992)

33 Myers CL, Desai SN, Schembri-King J, Letts GL and Wallace RW: Discriminatory effects of protein kinase inhibitors and calcium ionophore on endothelial ICAM-1 induction. Am J Physiol 262, C365-C373 (1992)

34 Myers CL, Wertheimer SJ, Schembri-King J, Parks $T$ and Wallace RW: Induction of ICAM-1 by TNF- $\alpha$, IL- $1 \beta$, and LPS in human endothelial cells after downregulation of PKC. Am J Physiol 263, C767-C772 (1992)

35 Lane TA, Lamkin GE and Wancewicz EV: Protein kinase C inhibitors block the enhanced expression of intercellular adhesion molecule-1 on endothelial cells activated by interleukin-1, lipopolysaccharide and tumor necrosis factor. Biochem Biophys Res Commun 172, 1273 - 1281 (1990)

36 Liebenhoff U, Greinacher A and Presek P: The protein tyrosine kinase pp $60^{\mathrm{c}-\mathrm{src}}$ is activated upon platelet stimulation. Cell Mol Biol (Noisy-le-grand) 40, 645-652 (1994)

37 Kiyomoto H, Fouqueray B, Abboud HE and Choudhury GG: Phorbol 12-myristate 13-acetic acid inhibits PTP1B activity in human mesangial cells. A possible mechanism of enhanced tyrosine phosphorylation. FEBS Lett 353, 217-220 (1994)

38 Tsujisaki $M$, Imai $K$, Hirata $H$, Hamazawa $\mathrm{Y}$, Masuya J, Nakano T, Sugiyama T, Matsui M, Hinoda $Y$ and Yachi A: Detection of circulating intercellular adhesion molecule- 1 in malignant disease. Clin Exp Immunol 85, 3-8 (1991)

39 Tang WW, Feng L, Vannice JL and Wilson CB: Interleukin-1 receptor antagonist ameliorates experimental anti-glomerular basement membrane antibody-associated glomerulonephritis. J Clin Invest 93, 273-279 (1994)

40 Mason J: The effects of Sandimmune on kidney. Clin Res Bull 6, $47-51$ (1989) 